\title{
Hydrothermal Stability and Performance of Silica-Zirconia Membranes for Hydrogen Separation in Hydrothermal Conditions
}

\author{
KAZUHIRO YOSHIDA ${ }^{1}$, YOSHIO HIRANO ${ }^{1}$, \\ HIRONORI FUJII ${ }^{2}$, TOSHINORI TSURU ${ }^{3}$ \\ AND MASASHI ASAEDA ${ }^{3}$ \\ ${ }^{1}$ Technical Research Center, The Chugoku Electric Power Co., Inc., \\ Higashi-Hiroshima 739-0046, Japan \\ ${ }^{2}$ The Chuden Kankyo Technos Co., Ltd., \\ Higashi-Hiroshima 739-0046, Japan \\ ${ }^{3}$ Department of Chemical Engineering, Hiroshima University, \\ Higashi-Hiroshima 739-8527, Japan
}

Keywords: Inorganic Membranes, Sol-Gel Method, Hydrogen Separation, Gas Separation, Silica

\begin{abstract}
Three types of silica-zirconia membranes of different zirconia content were prepared by the sol-gel method to test their stability and $\mathrm{H}_{2}$ separation performance in hydrothermal conditions. Some silicazirconia membranes were prepared by "steam-firing" in which firing was carried out in steamed air in order to increase the hydrothermal stability, and then tested in hydrothermal conditions. The activation energy of $\mathrm{H}_{2}$ and He permeation increased with increasing zirconia content, suggesting that the networks of silica-zirconia matrix were densified with increasing zirconia content. In the hydrothermal conditions, the activation energy of $\mathrm{H}_{2}$ and $\mathrm{He}$ permeation also increased, indicating clearly that silica-zirconia membranes were also densified by water vapor at high temperature. The pores for $\mathrm{N}_{2}, \mathrm{CO}_{2}$ and $\mathrm{CH}_{4}$ permeation decreased with the increasing zirconia content and vanished in the hydrothermal conditions, leaving some pinholes. Some silica-zirconia membranes were prepared by firing in steamed air in order to increase the hydrothermal stability. This method appeared to be effective to increase hydrothermal stability of the silica-zirconia membrane.
\end{abstract}

\section{Introduction}

In recent years, $\mathrm{CO}_{2}$ emissions from fossil fuels combustion are considered one of the major causes of global warming. In compliance with the conclusion of the Kyoto Protocol in COP3 (The 3rd Session of the Conference of the Parties to the United Nations Framework Convention on Climate Change in 1997), Japan is obliged to reduce her overall emission of the greenhouse gases by at least 6 per cent below the 1990 level in the commitment period 2008 to 2012. The electric power companies have been conducting activities to form energy supply structures with less $\mathrm{CO}_{2}$ exhaust such as promoting nuclear power generation and introducing high-efficiency power generation systems. Until now, we have depended on a lot of electricity from thermal power stations, consuming coal, petroleum and natural gas. This trend would be continued for a while, since the new energy systems such as solar power generation systems, wind power generation systems and fuel cell systems will take many more years to be put in practice in a large scale. In addition,

Received on September 6, 2000. Correspondence concerning this article should be addressed to K. Yoshida (E-mail address: 352357@pnet.energia.co.jp). the demand for electricity will continue to increase in the near future, causing more $\mathrm{CO}_{2}$ emissions. For the stable energy supply, we will be required to reduce $\mathrm{CO}_{2}$ emissions from thermal power stations by developing new systems for $\mathrm{CO}_{2}$ reduction.

Many researches have been reported on the $\mathrm{CO}_{2}$ reduction from the boiler flue gas by chemical absorption, physical adsorption or membrane separation (Mimura and Stumi, 1998, Mimura et al., 1998, 2000; Matsumiya et al., 1999). In case of $\mathrm{CO}_{2}$ recovery from the conventional fossil fuel power generation systems, however, a higher power cost would be inevitable because of the cost increase on the extra equipment and the decline of thermal efficiency. On the other hand, as one of the most efficient strategies of the reduction in $\mathrm{CO}_{2}$ emissions from thermal power stations has been proposed "the LNG reforming combined cycle power generation system with the $\mathrm{H}_{2}$-separation membrane" (Morinaga et al., 1992; Takahashi et al., 1999). In this system, natural gas is reformed into $\mathrm{H}_{2}, \mathrm{CO}$, etc. $\mathrm{H}_{2}$ is removed from the reforming reactor simultaneously by using $\mathrm{H}_{2}$-separation membranes. The residual gases including $\mathrm{CH}_{4}$ and $\mathrm{CO}$ are burned at an after-burner with pure $\mathrm{O}_{2}$ to give exhaust gas of a high $\mathrm{CO}_{2}$ concentration, which can be easily recovered. $\mathrm{H}_{2}$ removed from the reactor is fed to a gas turbine generation system. 
Table 1 Starting composition of silica-zirconia colloidal sols and average diameters of colloidal particles measured by laser light scattering system

\begin{tabular}{llcccccc}
\hline $\begin{array}{l}\text { Composition } \\
{\left[\mathrm{ZrO}_{2} \text { mol\%] }\right.}\end{array}$ & & $\begin{array}{c}\text { TEOS } \\
{[\mathrm{g}]}\end{array}$ & $\begin{array}{c}\mathrm{ZTBO} \\
{[\mathrm{g}]}\end{array}$ & $\begin{array}{c}\mathrm{H}_{2} \mathrm{O} \\
{[\mathrm{g}]}\end{array}$ & $\begin{array}{c}\mathrm{HCl}(35 \%) \\
{[\mathrm{g}]}\end{array}$ & $\begin{array}{c}\mathrm{C}_{2} \mathrm{H}_{5} \mathrm{OH} \\
{[\mathrm{g}]}\end{array}$ & $\begin{array}{c}\text { Colloidal diameter* } \\
{[\mathrm{nm}]}\end{array}$ \\
\hline $10(\mathrm{~S} 9-\mathrm{Z1})$ & sol-A & 4.15 & 0.85 & 1.99 & 0.59 & 207 & 49.1 \\
& sol-B & 3.32 & 0.68 & 1.60 & 0.59 & 165 & 35.3 \\
& sol-C & 1.66 & 0.34 & 0.80 & 0.59 & 82.7 & 10.2 \\
$30(\mathrm{~S} 7-\mathrm{Z3})$ & sol-A & 5.59 & 4.41 & 3.45 & 0.59 & 179 & 33.7 \\
& sol-B & 4.19 & 3.31 & 2.59 & 0.59 & 134 & 19.5 \\
& sol-C & 1.83 & 1.44 & 1.13 & 0.59 & 117 & 7.6 \\
$50(\mathrm{~S} 5-\mathrm{Z5})$ & sol-A & 5.10 & 9.40 & 4.41 & 0.59 & 229 & 47.9 \\
& sol-B & 4.41 & 7.45 & 3.50 & 0.59 & 181 & 22.4 \\
& sol-C & 1.41 & 2.59 & 1.22 & 0.59 & 94.6 & 8.3 \\
\hline
\end{tabular}

*after boiling the polymer solution for about 30 hours adding water and acid to the solution

Methane steam reforming involves the following main reactions:

$$
\begin{aligned}
& \mathrm{CH}_{4}+\mathrm{H}_{2} \mathrm{O} \leftrightarrow \mathrm{CO}+3 \mathrm{H}_{2} ; \quad \Delta H_{298}^{0}=206.1 \mathrm{kJmol}^{-1} \\
& \mathrm{CO}+\mathrm{H}_{2} \mathrm{O} \leftrightarrow \mathrm{CO}_{2}+\mathrm{H}_{2} ; \quad \Delta H_{298}^{0}=-41.2 \mathrm{kJmol}^{-1}
\end{aligned}
$$

High temperature and low-pressure are thermodynamically favorable conditions for the reactions, because the overall reforming reaction is endothermic and it gives the increase in mole number of the participating gases. If $\mathrm{H}_{2}$ is selectively removed from the reaction system, the thermodynamic equilibrium position of these reactions can be shifted to the product side, giving a higher conversion of $\mathrm{CH}_{4}$ to $\mathrm{H}_{2}$ and $\mathrm{CO}_{2}$ even at lower temperatures (Kikuchi, 1996). The key technology in the system mentioned above is the development of thermally stable $\mathrm{H}_{2}$-separation membranes in LNG reformed fuel gas processes. Inorganic separation membranes could be such membranes because of their provable high stability at high temperature.

Inorganic membranes have attracted increasing attention in the field of membrane science and technology because of their thermal and chemical stability. Many researchers have studied on the fabrication procedures of ceramic membranes by the chemical vapor deposition (CVD) and sol-gel methods. Amorphous silica $\left(\mathrm{SiO}_{2}\right)$ membranes have been shown to have a high $\mathrm{H}_{2}$-selective permeance and high stability in dry gases at high temperature (Gavalas and Megris, 1989; Kitao et al., 1990). In hydrothermal conditions, however, the $\mathrm{H}_{2}$ permeance of the CVD derived $\mathrm{SiO}_{2}$ membrane decreased drastically probably because of densification of silica matrix by water vapor at high temperature (Tsapatsis and Gavalas, 1994; Kim and Gavalas, 1995). Since the gas mixtures from LNG reforming processes contain high concentration of water vapor, the membranes are essentially required of the high stability in hydrothermal conditions.
Composite membranes of silica with the inorganic oxide such as titania $\left(\mathrm{TiO}_{2}\right)$ and zirconia $\left(\mathrm{ZrO}_{2}\right)$ are reported as better alternatives to silica membranes. These materials may combine the processing flexibility of silica together with better stability against thermally and chemically aggressive environments. Nogami and Moriya (1977) reported that the addition of $\mathrm{TiO}_{2}$ or $\mathrm{ZrO}_{2}$ to $\mathrm{SiO}_{2}$ was effective for the improvement of alkali resistance. The silica-zirconia $\left(\mathrm{SiO}_{2}-\right.$ $\mathrm{ZrO}_{2}$ ) composite $\mathrm{H}_{2}$-separation membranes were successfully prepared by the sol-gel method (Tsuru et al., 1996). Efforts to improve the hydrothermal stability of the $\mathrm{SiO}_{2}$ membrane by adding alumina $\left(\mathrm{Al}_{2} \mathrm{O}_{3}\right)$ are also in progress (Ha et al., 1998). For an application to the iodine-sulfur process, the CVD derived silica membranes were examined in $\mathrm{H}_{2}-\mathrm{H}_{2} \mathrm{O}-\mathrm{HI}$ gaseous mixtures (Hwang et al., 2000). The CVD derived SiC-based membranes were also examined in $\mathrm{H}_{2}-\mathrm{H}_{2} \mathrm{O}-\mathrm{HBr}$ system (Sea et al., 1998). The hydrophobic silica membranes were also prepared by incorporation of methyl groups in the silica microstructure (de Vos et al., 1999). On the other hand, $\mathrm{SiO}_{2}$ membranes were reported to become quite sable against steam at high temperature by keeping coated membranes in humid air for a few days and firing them in steam (Asaeda and Kashimoto, 1998).

In this work, three types of $\mathrm{SiO}_{2}-\mathrm{ZrO}_{2}$ membranes with different $\mathrm{ZrO}_{2}$ contents were prepared by the solgel methods. The $\mathrm{SiO}_{2}-\mathrm{ZrO}_{2}$ membranes were fired in air and in steamed air to test their stability and $\mathrm{H}_{2}$ separation performance in hydrothermal conditions. The effects of $\mathrm{ZrO}_{2}$ contents and steam treatments on $\mathrm{H}_{2}$ permeance are discussed in details.

\section{Experimental}

\subsection{Preparation of colloidal sols}

$\mathrm{SiO}_{2}-\mathrm{ZrO}_{2}$ composite colloidal sols of molar ratios $9 / 1,7 / 3$ and $5 / 5$ were prepared by hydrolysis and 


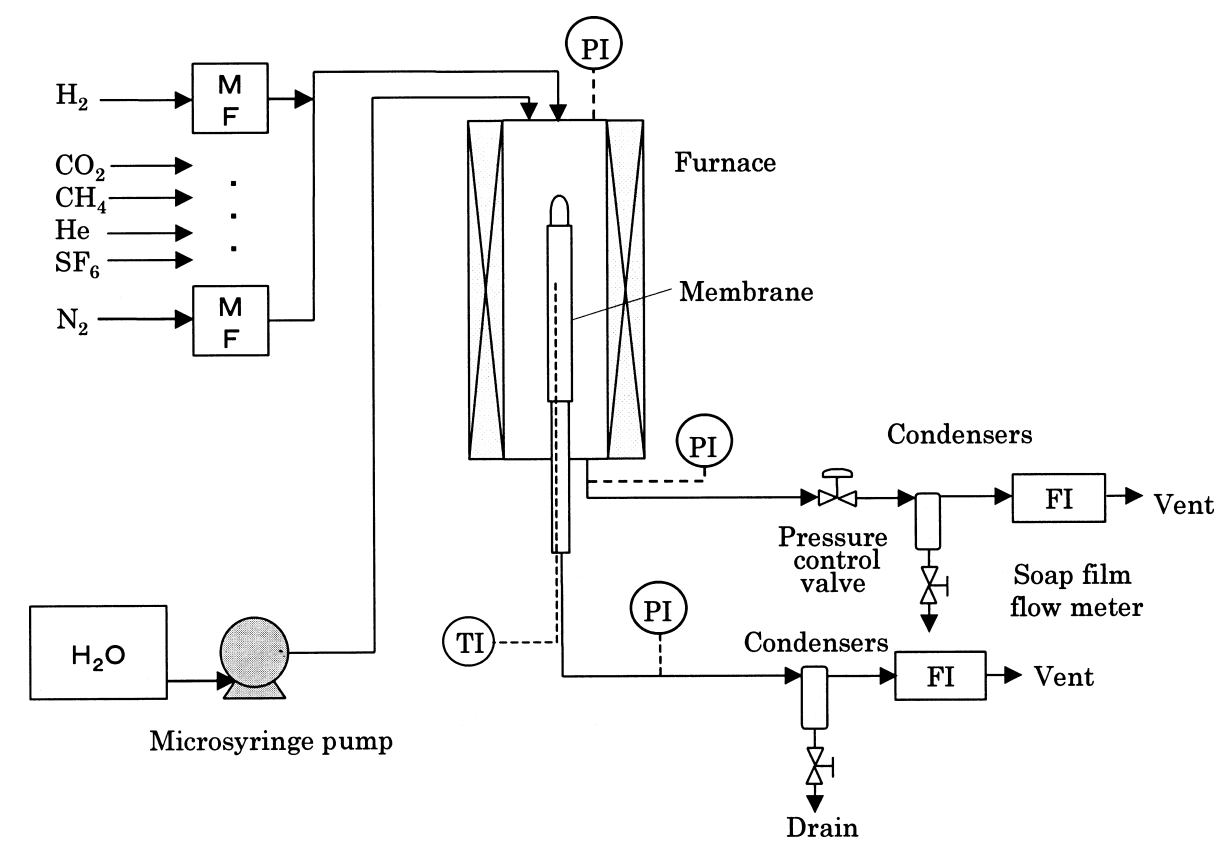

Fig. 1 Schematic diagram of the experimental set-up

condensation reactions of tetraethoxysilane (TEOS) and zirconium-tetra-butoxide (ZTBO). TEOS was partially pre-hydrolyzed in ethanol and then added ZTBO for 30 minutes of hydrolysis and condensation reactions to obtain $\mathrm{SiO}_{2}-\mathrm{ZrO}_{2}$ polymer sol at $4{ }^{\circ} \mathrm{C}$. After adding a large amount of water and hydrochloric acid in order to control the concentration and $\mathrm{pH}$, the solution was boiled for 30 hours to obtain a colloidal sol. The starting compositions of the sols prepared are shown in Table 1. The average colloid diameters of the sols were measured by a laser light scattering system (Zetasizer2000HS, Malvern Instruments).

\subsection{Preparation of $\mathrm{SiO}_{2}-\mathrm{ZrO}_{2}$ membranes}

Three types of $\mathrm{SiO}_{2}-\mathrm{ZrO}_{2}$ membranes of molar ratios 9/1 (S9-Z1), 7/3 (S7-Z3) and 5/5 (S5-Z5) were prepared by coating the sol on cylindrical $\alpha$-alumina porous tubes (average pore diameter: $1 \mu \mathrm{m}$, outer diameter: $1 \mathrm{~cm}$, length: $9 \mathrm{~cm}$ ). First of all, $\alpha$-alumina particles of average diameters $1.84,0.64$ and $0.2 \mu \mathrm{m}$, were coated on the outer surface of the tubes with solA as a binder to make the surface sufficiently flat and to reduce the pore diameter. The hot coating method (Asaeda et al., 1992) was applied. The substrate, which was heated approximately up to $190^{\circ} \mathrm{C}$, was coated with the diluted sol solution, then it was fired at $570^{\circ} \mathrm{C}$ for 15 minutes in a temperature-controlled electric furnace. These procedures were repeated several times with the sols of larger particle diameter to smaller one. Some of the $\mathrm{SiO}_{2}-\mathrm{ZrO}_{2}$ membranes of molar ratio 9/1 were also prepared by firing in steamed air (50 vol\% of steam) at $570^{\circ} \mathrm{C}$.

\subsection{Measurements of gas permeance}

In the first step, permeances of pure $\mathrm{He}, \mathrm{H}_{2}, \mathrm{~N}_{2}$, $\mathrm{CO}_{2}, \mathrm{CH}_{4}$ and $\mathrm{SF}_{6}$ were measured in the temperature
Table 2 Experimental conditions (feed) of hydrothermal stability tests

\begin{tabular}{lcccccc}
\hline & \multicolumn{3}{c}{ Partial pressure $[\mathrm{kPa}]$} & & Total pressure & Temperature \\
\cline { 2 - 4 } & $\mathrm{H}_{2} \mathrm{O}$ & $\mathrm{H}_{2}$ & $\mathrm{~N}_{2}$ & {$[\mathrm{kPa}]$} & {$[\mathrm{K}]$} \\
\hline Test I & 40 & 130 & 130 & 300 & 773 \\
Test II & 100 & 100 & 100 & 300 & 773 \\
Test III & 200 & 200 & 200 & 600 & 773 \\
\hline
\end{tabular}

range of $200-500^{\circ} \mathrm{C}$ by using an apparatus schematically shown in Fig. 1. The gas flow rate on the feed side was controlled by mass flow controllers and a pressure control valve to maintain the pressure difference across the membrane at $0.1 \mathrm{MPa}$, while the permeate side was kept at the atmospheric pressure. The permeation rate was measured by a soap film flow meter (SF-1, STEC).

In the second step, the $\mathrm{SiO}_{2}-\mathrm{ZrO}_{2}$ membranes were hydrothermally treated at $500^{\circ} \mathrm{C}$ in a gas mixture $\left(\mathrm{H}_{2}\right.$, $\mathrm{N}_{2}$ and $\mathrm{H}_{2} \mathrm{O}$ ). The composition of the gas mixture was controlled by mass flow controllers and by a microsyringe pump. The experimental conditions of hydrothermal stability tests are shown in Table 2 . The pressure on the permeate side was maintained at the atmospheric pressure in these tests. After specified time intervals of hydrothermal treatments, the water feed was stopped and the permeation cell was dried completely before measurements of pure $\mathrm{H}_{2}$ and $\mathrm{N}_{2}$ permeances. After 10 hours of each hydrothermal stability test, the temperature dependency of the permeances of the pure gases were measured in the temperature range $200-500^{\circ} \mathrm{C}$. 


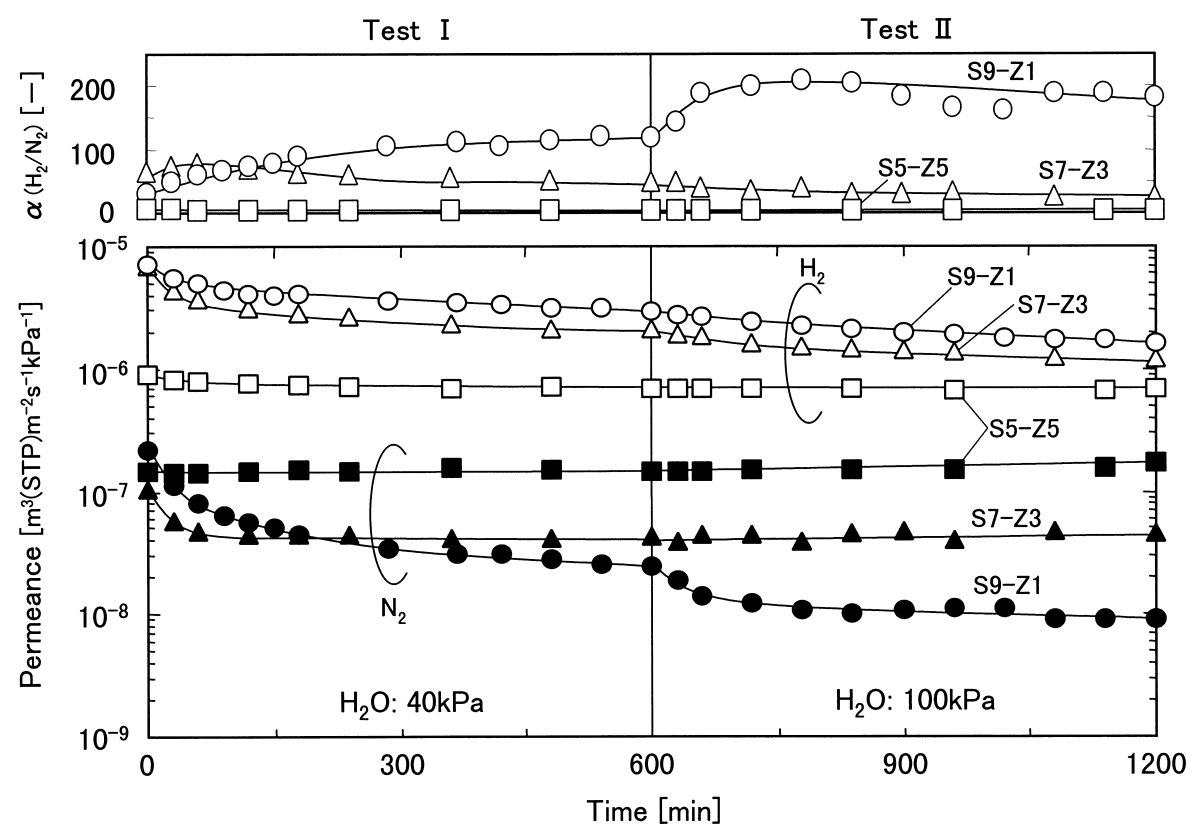

Fig. 2 Permeances of pure $\mathrm{H}_{2}$ and $\mathrm{N}_{2}$ and $\alpha\left(\mathrm{H}_{2} / \mathrm{N}_{2}\right)$ at $500^{\circ} \mathrm{C}$ as a function of hydrothermal time. Partial pressure of $\mathrm{H}_{2} \mathrm{O}: 40$ $\mathrm{kPa}(0-600 \mathrm{~min}), 100 \mathrm{kPa}(600-1200 \mathrm{~min})$

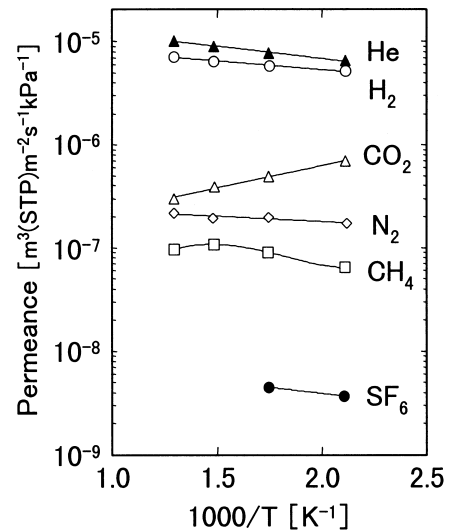

(a) Fresh

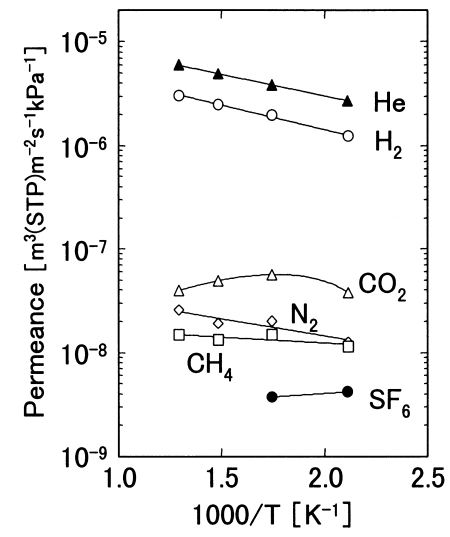

(b) after Test I

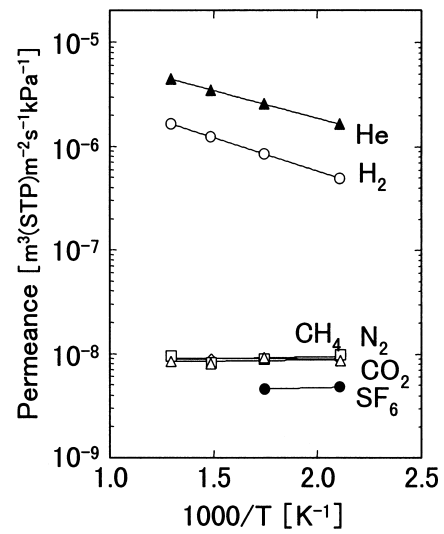

(c) after Test II

Fig. 3 Arrhenius plots of permeances through the S9-Z1 membrane before and after hydrothermal stability tests

\section{Results and Discussion}

\subsection{Hydrothermal stability of $\mathrm{SiO}_{2}-\mathrm{ZrO}_{2}$ mem- branes}

Figure 2 shows the observed permeance changes of pure $\mathrm{H}_{2}$ and $\mathrm{N}_{2}$ during the hydrothermal tests at $500^{\circ} \mathrm{C}$. In the test I (partial pressure of water vapor; $40 \mathrm{kPa}$ ), the permeances of $\mathrm{H}_{2}$ and $\mathrm{N}_{2}$ through $\mathrm{S} 9-\mathrm{Z} 1$ and S7-Z3 membranes decreased drastically during the first 60 minutes, and slightly from 60 to 600 minutes, and approached to constant values. Under a higher partial pressure of water vapor $(100 \mathrm{kPa})$ in test II, the $\mathrm{H}_{2}$ permeances of $\mathrm{S} 9-\mathrm{Z} 1$ and $\mathrm{S} 7-\mathrm{Z} 3$ membranes decreased gradually, while $\mathrm{N}_{2}$ permeance of $\mathrm{S} 9-\mathrm{Z} 1$ membrane decreased drastically, but that of S7-Z3 membrane showed little change. After test II, the S9-Z1 membrane showed a permeability ratio $\alpha\left(\mathrm{H}_{2} / \mathrm{N}_{2}\right)$ of 190 and $\mathrm{H}_{2}$ permeance of $0.2 \times 10^{-5} \mathrm{~m}^{3}(\mathrm{STP}) \mathrm{m}^{-2}$ $\mathrm{s}^{-1} \mathrm{kPa}^{-1}$, which are larger than the targets of a membrane performance suggested by Morinaga et al. (1992). On the other hand, the $\mathrm{H}_{2}$ and $\mathrm{N}_{2}$ permeances of S5-Z5 membrane did not show any change after 1,200-minute exposures to high temperature steam in tests I and II, resulting in a constant selectivity of 4.0.

Figures 3-5 show the Arrhenius plots of permeances before and after hydrothermal stability tests for the S9-Z1, S7-Z3 and S5-Z5 membranes, respectively. The permeation of $\mathrm{He}$ and $\mathrm{H}_{2}$ through the fresh S9-Z1 membrane (Fig. 3(a)) showed a characteristic of activated diffusion (permeation), in which the permeance becomes greater with the temperature in- 


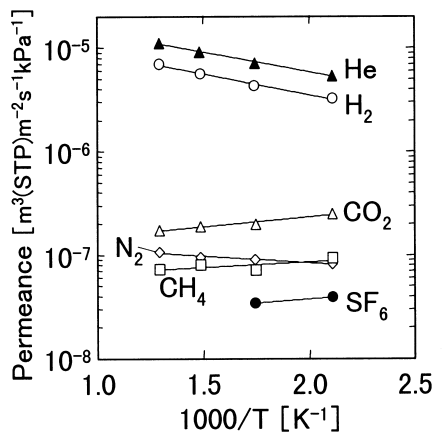

(a) Fresh

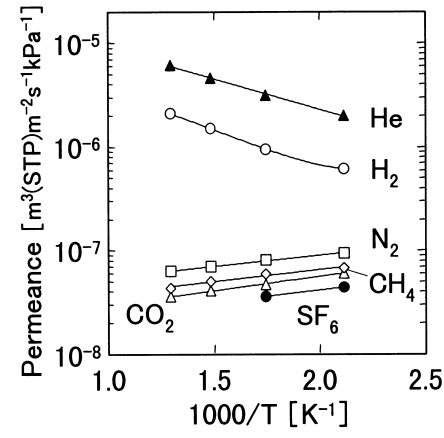

(b) after Test I

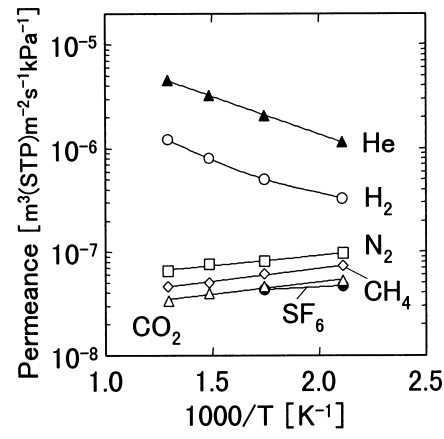

(c) after Test II

Fig. 4 Arrhenius plots of permeances through the S7-Z3 membrane before and after hydrothermal stability tests

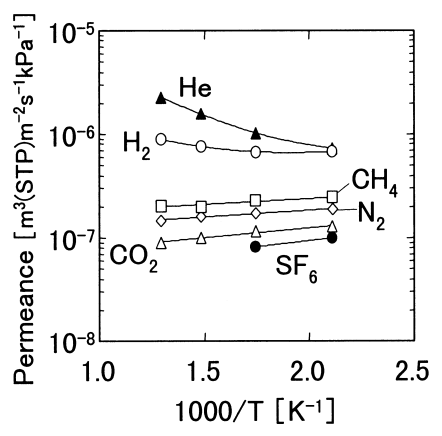

(a) Fresh

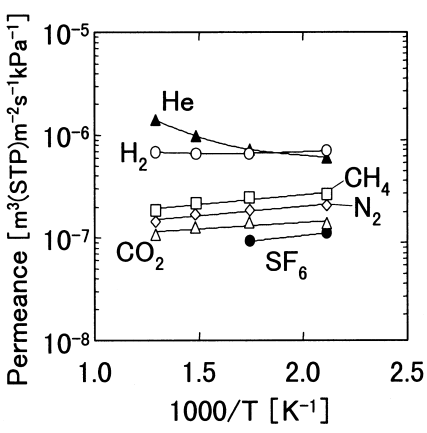

(b) after Test I

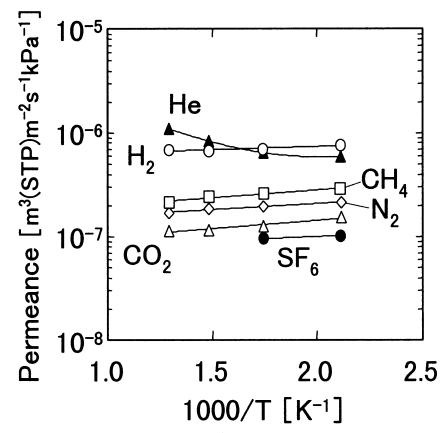

(c) after Test II

Fig. 5 Arrhenius plots of permeances through the S5-Z5 membrane before and after hydrothermal stability tests

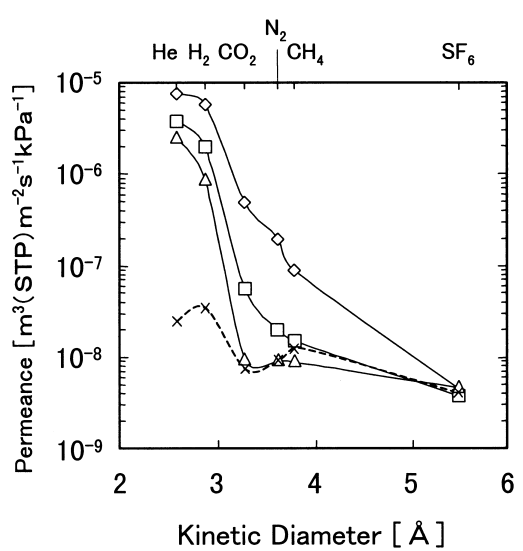

(a) $\mathrm{S} 9-\mathrm{Z1}$

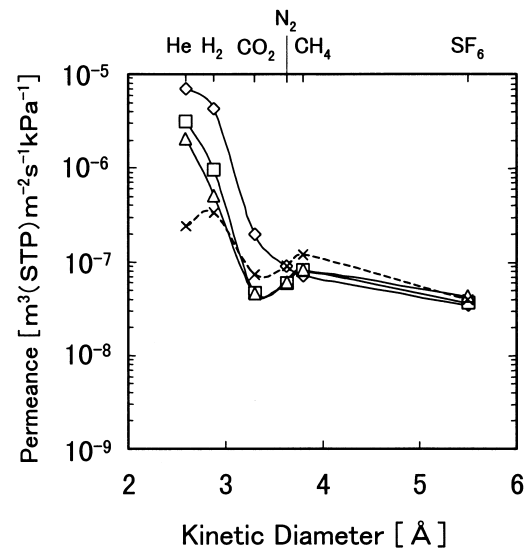

(b) $57-\mathrm{Z3}$

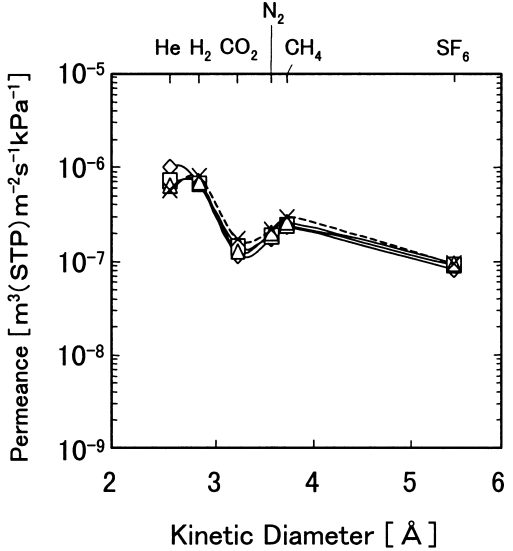

(c) $\mathrm{S} 5-\mathrm{Z} 5$

Fig. 6 Permeances for S9-Z1, S7-Z3 and S5-Z5 membranes at $300^{\circ} \mathrm{C}$ before and after hydrothermal stability test as a function of kinetic diameters: $(\diamond)$ fresh, $(\square)$ after test I, $(\triangle)$ after test II and $(\times)$ Knundsen diffusion (based on SF $_{6}$ permeate)

crease. This tendency was strengthened after hydrothermal stability tests and the permeances of $\mathrm{H}_{2}$ and He decrease as shown in Figs. 3(b) and (c). The permeation of $\mathrm{N}_{2}$ and $\mathrm{CH}_{4}$ through the fresh $\mathrm{S} 9-\mathrm{Z} 1 \mathrm{mem}-$ brane showed characteristics of activated diffusion, while $\mathrm{CO}_{2}$ permeation seems to be due to surface diffusion. After test $\mathrm{I}$, the permeances of $\mathrm{N}_{2}, \mathrm{CH}_{4}$ and $\mathrm{CO}_{2}$ decreased drastically, and showed nearly the same value after test II. On the other hand, $\mathrm{SF}_{6}$ permeance did not change before and after the hydrothermal stability tests. In case of the S7-Z3 membrane (Fig. 4), the permeances of $\mathrm{He}$ and $\mathrm{H}_{2}$ showed a tendency similar to those of S9-Z1 membrane after the hydrothermal stability tests. Although the permeation of $\mathrm{N}_{2}$ 
Table 3 Activation energy of $\mathrm{H}_{2}$ and He permeation through the silica-zirconia membranes $[\mathrm{kJ} / \mathrm{mol}]$

\begin{tabular}{|c|c|c|c|c|c|c|}
\hline \multirow{2}{*}{$\begin{array}{l}\text { Partial pressure of water } \\
\qquad[\mathrm{kPa}]\end{array}$} & \multicolumn{3}{|c|}{$\mathrm{H}_{2}$} & \multicolumn{3}{|c|}{$\mathrm{He}$} \\
\hline & S9-Z1 & S7-Z3 & S5-Z5 & S9-Z1 & S7-Z3 & S5-Z5 \\
\hline 0 (fresh membrane) & 3.4 & 8.1 & 44 & 4.7 & 7.6 & 22 \\
\hline 40 (test I) & 9.2 & 17.0 & - & 8.0 & 12 & 30 \\
\hline 100 (test II) & 13 & 30 & 一 & 10 & 15 & 32 \\
\hline
\end{tabular}

through the fresh S7-Z3 membrane (Fig. 4(a)) showed the characteristic of activated diffusion, the permeation behavior changed into the Knudsen-like diffusion after test I (Fig. 4(b)), and it did not change after test II (Fig. 4(c)). The $\mathrm{CO}_{2}$ permeance decreased drastically after test I, and it did not change further after test II. These results seem to show that the pores which allowed the permeation of $\mathrm{He}$ and $\mathrm{H}_{2}$ became smaller during hydrothermal stability tests, while the pores for $\mathrm{N}_{2}, \mathrm{CH}_{4}$ and $\mathrm{CO}_{2}$ permeation changed into larger pores in which the Knudsen diffusion prevailed. The S5-Z5 membrane (Fig. 5) showed a poor selective permeation for $\mathrm{H}_{2}$ and $\mathrm{He}$. The He permeation showed activated diffusion, but the $\mathrm{H}_{2}$ permeation showed the Knudsen-like diffusion after test I (Fig. 5(b)). For larger molecules such as $\mathrm{N}_{2}, \mathrm{CH}_{4}, \mathrm{CO}_{2}$ and $\mathrm{SF}_{6}$, the permeation mechanism is the Knudsen-like diffusion. This tendency was unchanged through the hydrothermal stability tests as shown in Figs. 5(a)-(c). The results in Figs. 3-5 indicate that the $\mathrm{H}_{2}$ permeance decreases with increasing $\mathrm{ZrO}_{2}$ content, giving a poor ideal selectivity of $\alpha\left(\mathrm{H}_{2} / \mathrm{N}_{2}\right)$.

Figures 6 show the gas permeances as a function of kinetic diameters before and after hydrothermal stability tests at $300^{\circ} \mathrm{C}$. The dotted curves in these figures are obtained by assuming the Knudsen diffusion based on the $\mathrm{SF}_{6}$ permeance. Comparing the observed results with these dotted curves, the permeation of $\mathrm{N}_{2}$, $\mathrm{CH}_{4}$ and $\mathrm{CO}_{2}$ through the S9-Z1 (Fig. 6(a)) and the S7-Z3 (Fig. 6(c)) membranes shows the Knudsen-like diffusion after hydrothermal stability tests. In case of the S5-Z5 membrane (Fig. 6(c)), the permeation of $\mathrm{N}_{2}$, $\mathrm{CH}_{4}, \mathrm{CO}_{2}$ and $\mathrm{H}_{2}$ did not change even after hydrothermal stability tests, and shows the Knudsen-like diffusion. The results in Figs. 6(a) and (b) show that the pores through which $\mathrm{N}_{2}, \mathrm{CO}_{2}$ and $\mathrm{CH}_{4}$ can permeate, have vanished during hydrothermal stability tests, leaving some pinholes which seem quite stable in hydrothermal conditions.

$\mathrm{He}$ and $\mathrm{H}_{2}$ can be considered to permeate through small pores in dense $\mathrm{SiO}_{2}-\mathrm{ZrO}_{2}$ networks by activated diffusion. The activation energy probably depends on the $\mathrm{ZrO}_{2}$ content and the tightness of the dense phase, as shown in Figs. 3-5. The activation energy can be obtained from the temperature dependency of permeance after subtracting the contribution of the Knudsen diffusion, based on $\mathrm{N}_{2}$ permeance, through
Table 4 BET surface areas of the $\mathrm{SiO}_{2}-\mathrm{ZrO}_{2}$ powder after firing 30 minutes in air or in steamed air at $570^{\circ} \mathrm{C}$ $\left[\mathrm{m}^{2} / \mathrm{g}\right]$

\begin{tabular}{lcccc}
\hline Firing conditions & $\mathrm{Pure}^{\mathrm{SiO}_{2}}$ & $\mathrm{~S} 9-\mathrm{Z1}$ & $\mathrm{S} 7-\mathrm{Z3}$ & $\mathrm{S} 5-\mathrm{Z5}$ \\
\hline In air & 406.7 & 519.7 & 77.4 & 75.0 \\
In steam & 277.9 & 482.4 & 63.3 & 70.4 \\
\hline
\end{tabular}

the pinholes. Table 3 summarizes the activation energy of $\mathrm{H}_{2}$ and $\mathrm{He}$ permeation. The activation energies of $\mathrm{H}_{2}$ and $\mathrm{He}$ permeation increased with increasing $\mathrm{ZrO}_{2}$ content, suggesting that the network of $\mathrm{SiO}_{2}-\mathrm{ZrO}_{2}$ matrix was densified with increasing $\mathrm{ZrO}_{2}$ content. They also increased, in the hydrothermal conditions, indicating clearly that $\mathrm{SiO}_{2}-\mathrm{ZrO}_{2}$ membranes were also densified by water vapor at high temperature.

In order to elucidate the effects of $\mathrm{ZrO}_{2}$ content and water vapor at high temperature on the pores for $\mathrm{N}_{2}$ permeation, specific surface areas of pure $\mathrm{SiO}_{2}, \mathrm{~S} 9$ Z1, S7-Z3 and S5-Z5 powders were measured by BET method (Micromeritics, ASAP2000). These powders were prepared by drying $\mathrm{SiO}_{2}$ and $\mathrm{SiO}_{2}-\mathrm{ZrO}_{2}$ sol solutions at $150^{\circ} \mathrm{C}$, and then fired in air or in steamed air $\left(\mathrm{H}_{2} \mathrm{O}: 50 \mathrm{kPa}\right)$ at $570^{\circ} \mathrm{C}$ for 30 minutes. Table 4 shows the BET surface areas of $\mathrm{SiO}_{2}$ and $\mathrm{SiO}_{2}-\mathrm{ZrO}_{2}$ powders. The specific surface area of $\mathrm{SiO}_{2}$ decreased drastically, while that of S9-Z1 decreased slightly. This clearly shows that introduction of $\mathrm{ZrO}_{2}$ into $\mathrm{SiO}_{2}$ matrix leads to higher hydrothermal stability. But the specific surface area of S9-Z1 powder seems to decrease further by firing in higher water vapor pressure, as shown in Fig. 6(a). On the other hand, specific surface areas of S7-Z3 and S5-Z5 powders were small, suggesting that the pores for $\mathrm{N}_{2}$ permeation decrease with increasing $\mathrm{ZrO}_{2}$ content, as can be seen from Figs. 6(b) and (c).

\subsection{Hydrothermal stability of membranes prepared by steam-firing}

Figure 7 compares the pure $\mathrm{N}_{2}$ and $\mathrm{H}_{2}$ permeances of a steam-fired membrane and an air-fired membrane at $500^{\circ} \mathrm{C}$ as a function of treatment time. At the beginning, $\mathrm{H}_{2}$ permeances through both membranes showed almost the same value. In test $\mathrm{I}$, the $\mathrm{H}_{2}$ and $\mathrm{N}_{2}$ permeances of an air-fired membrane decreased drastically during the first 60 minutes, and slightly from 60 to 600 minutes, as described previously. The $\mathrm{H}_{2}$ and $\mathrm{N}_{2}$ permeances of a steam-fired membrane did show 
Table 5 Activation energy of $\mathrm{H}_{2}$ permeation through a membrane fired in steamed air and in air

\begin{tabular}{|c|c|c|}
\hline \multirow{2}{*}{$\begin{array}{c}\text { Partial pressure of water vapor } \\
\qquad[\mathrm{kPa}]\end{array}$} & \multicolumn{2}{|c|}{ Activation energy of $\mathrm{H}_{2}$ permeation $[\mathrm{kJ} / \mathrm{mol}]$} \\
\hline & $\begin{array}{l}\text { A membrane } \\
\text { fired in steam }\end{array}$ & $\begin{array}{l}\text { A membrane } \\
\text { fired in air }\end{array}$ \\
\hline 0 (fresh membrane) & 6.6 & 3.2 \\
\hline 40 (test I) & 7.4 & 9.1 \\
\hline 100 (test II) & 12.9 & 12.4 \\
\hline 200 (test III) & 15.2 & 15.5 \\
\hline
\end{tabular}

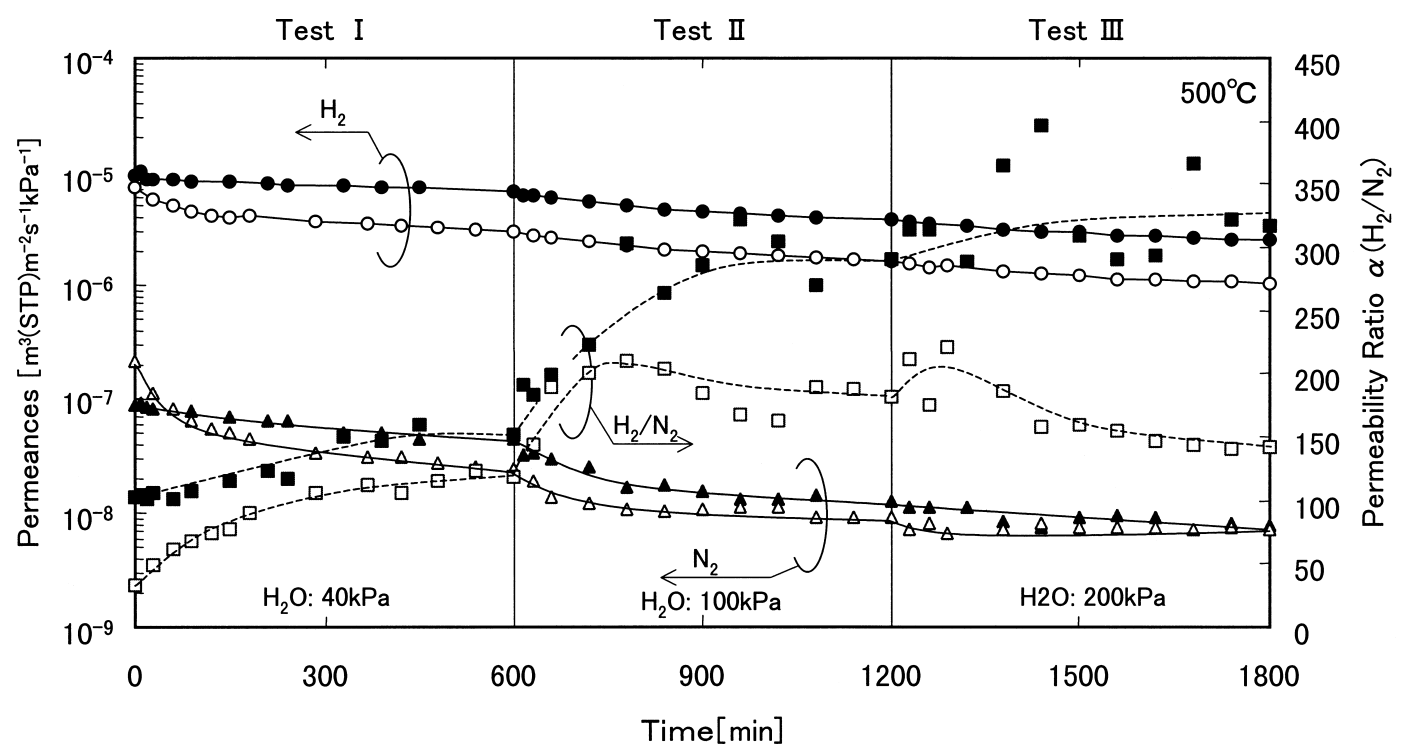

Fig. 7 Permeances of pure $\mathrm{N}_{2}$ and $\mathrm{H}_{2}$ and permeability ratio $\alpha\left(\mathrm{H}_{2} / \mathrm{N}_{2}\right)$ at $500^{\circ} \mathrm{C}$ as a function of hydrothermal treatment time $(\bullet, \boldsymbol{\Lambda}, \mathbf{\square}$ : a membrane fired in stream, $\bigcirc, \triangle, \square$ : a membrane fired in air)

gradual decrease from the beginning of the test I. This is probably due to the water vapor pressure lower than that in the membrane preparation. In tests II and III, where water vapor pressure was higher than that in the membrane preparation, the $\mathrm{H}_{2}$ and $\mathrm{N}_{2}$ permeances through the steam-fired membrane showed the same tendency as those through the air-fired membrane. After the hydrothermal stability tests, however, the $\mathrm{H}_{2}$ permeance of a steam-fired membrane showed a higher value than an air-fired membrane, while the $\mathrm{N}_{2}$ permeance showed almost the same value. Table 5 compares the activation energy of $\mathrm{H}_{2}$ permeation through a steam-fired and an air-fired membrane before and after the hydrothermal stability tests. The activation energy for the steam-fired membrane increased slightly after test I and increased drastically after test II, while that of an air-fired membrane showed a stepwise increase after each hydrothermal stability test. Though a steam-firing membrane would be also densified in higher water vapor pressure at high temperature, the steam-firing methods seem to be effective to increase the hydrothermal stability of the membranes.

\section{Conclusion}

Three types of silica-zirconia membranes with different zirconia contents were prepared by the solgel methods. Their hydrothermal stability and $\mathrm{H}_{2}$ separation performance were tested. Some silica-zirconia membranes were also prepared by firing them in steamed air to test their stability and $\mathrm{H}_{2}$ separation performance in hydrothermal conditions.

The activation energy of $\mathrm{H}_{2}$ and He permeation increased with the increase in zirconia content, suggesting that the network of the silica-zirconia matrix were densified with the increase in zirconia content. The pores for $\mathrm{N}_{2}, \mathrm{CO}_{2}$ and $\mathrm{CH}_{4}$ permeation decreased with the increasing zirconia content. In the hydrothermal conditions, the activation energy of $\mathrm{H}_{2}$ and $\mathrm{He}$ permeation also increased, indicating clearly that silicazirconia membranes were also densified by water vapor at high temperature. In the hydrothermal conditions, the pores for $\mathrm{N}_{2}, \mathrm{CO}_{2}$ and $\mathrm{CH}_{4}$ permeation vanish, leaving some pinholes. The steam-firing method appears to be effective to increase hydrothermal stability of silica-zirconia membranes. 


\section{Literature Cited}

Asaeda, M. and M. Kashimoto; "Sol-Gel Derived Silica Membranes for Separation of Hydrogen at High Temperature-Separation Performance and Stability against Steam-," Proc. Fifth Intern. Conf. on Inorg. Membr., p. 172-173, Nagoya, Japan (1998)

Asaeda, M., K. Okazaki and A. Nakatani; "Preparation of Thin Porous Silica Membranes for Separation of Non-Aqueous Organic Solvent Mixtures by Pervaporation," Ceramic Trans., 31, 411420 (1992)

de Vos, R. M., W. F. Maier and H. Verweij; "Hydrophobic Silica Membranes for Gas Separation," J. Membr. Sci., 158, 277-288 (1999)

Gavalas, G. R. and C. E. Megris; "Deposition of $\mathrm{H}_{2}$-Permselective SiO Films," Chem. Eng. Sci., 44, 1829-1835 (1989)

Ha, H. Y., S. W. Nam and S.-A. Hong; "Fabrication and Characterization of Alumina-Silica Composite Membranes Formed by MOCVD," Proc. Fifth Intern. Conf. on Inorg. Membr., p. 6265, Nagoya, Japan (1998)

Hwang, G.-J., K. Onuki and S. Shimizu; "Separation of Hydrogen from a $\mathrm{H}_{2}-\mathrm{H}_{2} \mathrm{O}-\mathrm{HI}$ Gaseous Mixture Using a Silica Membrane,' AIChE J., 1, 92-98 (2000)

Kikuchi, E.; "Steam Reforming and Related Reactions in Hydrogen-Permselective Membrane Reactor," Sekiyu Gakkaishi, 39 301-313 (1996)

Kim, S. and G. R. Gavalas; "Preparation of $\mathrm{H}_{2}$ Permselective Silica Membranes by Alternating Reactant Vapor Deposition," Ind. Eng. Chem. Res., 34, 168-176 (1995)

Kitao, S., H. Kameda and M. Asaeda; "Gas Separation by Thin Porous Silica Membrane of Ultra Fine Pores at High Temperature," Membrane, 15, 222-227 (1990)

Matsumiya, N., N. Inoue, H. Mano and K. Haraya; "Effect of Water Vapor on $\mathrm{CO}_{2}$ Separation Performance of Membrane Separator," Kagaku Kogaku Ronbunshu, 25, 367-373 (1999)
Mimura, T. and S. Stumi; "Evaluation of Power Loss for $\mathrm{CO}_{2} \mathrm{Re}$ covery from Flue Gas of Fossil Fuel-Fired Power Plant by Chemical Absorption Method," Kagaku Kogaku Ronbunshu, 24, 546-551 (1998)

Mimura, T., S. Stumi, T. Suda, M. Iijima and S. Mitsuoka; "Optimum Operations of $\mathrm{CO}_{2}$ Recovery Process by Chemical Absorption," Kagaku Kogaku Ronbunshu, 24, 1-4 (1998)

Mimura, T., K. Matumoto, M. Iijima and S. Mitsuoka; “Applicability of Chemical Absorption Process to Carbon Dioxide Removal and Recovery under Effluent Gas Conditions of Coal-Fired Power Plant," Kagaku Kogaku Ronbunshu, 26, 6-10 (2000)

Morinaga, M., H. Moritsuka and H. Makino; "Development of $\mathrm{CO}_{2}$ Recovery Thermal Power Generation Systems," Criepei Report W92029 (1992)

Nogami, M. and Y. Moriya; "On the Properties of Non-Crystalline Films Containing $\mathrm{TiO}_{2}$ and $\mathrm{ZrO}_{2}$ Prepared from Metal Alkoxides_-Alkali Resistance and Refractive Index_," YogyoKyokai-Shi, 85, 28-34 (1977)

Sea, B.-K., K. Ando, K. Kusakabe and S. Morooka; "Separation of Hydrogen from Steam Using a SiC-Based Membrane Formed by Vapor Deposition of Triisopropylsilane," J. Membr. Sci., 146, 73-82 (1998)

Takahashi, K., K. Watanabe and H. Moritsuka; "Hydrogen Decomposed Turbine Systems for Carbon Dioxide Recovery," Criepei Report W98011 (1999)

Tsapatsis, M. and G. Gavalas; "Structure and Aging Characteristics of $\mathrm{H}_{2}$-Permselective $\mathrm{SiO}_{2}$-Vycor Membranes," J. Membr. Sci., 87, 281-296 (1994)

Tsuru, T., F. Sago and M. Asaeda; "Silica and Silica-Zirconia Membranes for Hydrogen Separation at High Temperature," Proc. Fourth Intern. Conf. on Inorg. Membr., p. 111-118, Gatlinburg, TN, USA (1996) 